Article

\title{
Piracy and the Politics of Social Media
}

\author{
Martin Fredriksson Almqvist \\ Department for Culture Studies, Linköping University, 60174 Norrköping, Sweden; \\ martin.fredriksson@liu.se; Tel.: +46-11-363-492 \\ Academic Editor: Terri Towner \\ Received: 13 June 2016; Accepted: 20 July 2016; Published: 5 August 2016
}

\begin{abstract}
Since the 1990s, the understanding of how and where politics are made has changed radically. Scholars such as Ulrich Beck and Maria Bakardjieva have discussed how political agency is enacted outside of conventional party organizations, and political struggles increasingly focus on single issues. Over the past two decades, this transformation of politics has become common knowledge, not only in academic research but also in the general political discourse. Recently, the proliferation of digital activism and the political use of social media are often understood to enforce these tendencies. This article analyzes the Pirate Party in relation to these theories, relying on almost 30 interviews with active Pirate Party members from different parts of the world. The Pirate Party was initially formed in 2006, focusing on copyright, piracy, and digital privacy. Over the years, it has developed into a more general democracy movement, with an interest in a wider range of issues. This article analyzes how the party's initial focus on information politics and social media connects to a wider range of political issues and to other social movements, such as Arab Spring protests and Occupy Wall Street. Finally, it discusses how this challenges the understanding of information politics as a single issue agenda.
\end{abstract}

Keywords: piracy; Pirate Party; political mobilization; political parties; information politics; social media; activism

\section{Introduction}

Throughout the 1990s, the conceptions of politics in the Western world changed in certain ways. In the early part of the decade, the impact of the environmental movement, the growth of identity politics, and the decline of the traditional political parties forced theorists to reconsider how and where politics are made. Ulrich Beck used the term subpolitics (or sub(system)politics) to describe how political struggles increasingly took place outside of the institutionalized political system, focusing on issues previously excluded from the established political agendas: "The old industrial consensus built into the social system is encountering new and different fundamental convictions: ecological, feminist, and many others" ([1], p. 52). Beck described how the hegemony of left-right politics and the parliamentary party system was challenged by new social movements propagating political issues outside of the confines of party politics. This new kind of politics was formed in alternative social movements, but it took place most notably in people's everyday lives and in the choices and acts they made as individuals, citizens, and consumers [1,2]. This pointed towards a political landscape where parliamentary structures and established institutions were no longer the primary site for political agency. A landscape emerged where the old ideologies and their grand narratives gave way to subpolitical struggles undertaken in everyday life and in heterogeneous social movements consisting of free individuals engaging temporarily through different communicative networks [3].

More recently, the rise of digital activism and social media as a tool for political campaigning has added new dimensions to the changing political landscape. The proliferation of digital technologies and their impact on ordinary people's everyday lives can be seen to confirm the individualization of politics 
that began in the 1990s. Stefania Milan has conceptualized this as "cloud protesting": a term she uses to describe "a type of social organizing for collective action with individuals and their needs, preferences, bodies, and individualities at its core" ([4], p. 198). The term refers to digital communication technologies that let individuals "tailor" their participation according to their own private motifs and values, and to take part in fluid local and global constellations without compromising their personal agendas. The cloud is described as being "composed of blogs, social networking and microblogging platforms, and other tools such as digital storytelling websites. Such imagined space is to be intended in the guise of a symbolic space between technology devices and platforms" ([4], p. 200). These kinds of digitized protest movements are increasingly becoming internationalized, or "transnationally framed" as Milan puts it ([5], p. 138). The political potential of social media was particularly emphasized after the Arab Spring and the rapid spread of different protest movements, from Syria, through Syntagma Square, to the occupation of Wall Street. These were often understood and analyzed as parallel, and sometimes interconnected, movements partly mobilized through social media campaigns [6,7].

Since the Arab Spring, the idea of the demise of the political party has, however, been challenged by a wave of new political parties. As early as 2007 Andrew Chadwick noted that instead of replacing the political parties, digital activism could actually revive them as new social movements hybridized with political parties. Chadwick and Strommer-Galley have shown that digital technologies may not only contribute to the formation of new parties but also challenge the power concentration within established parties by empowering grass roots movement within those organizations [8,9]. The more recent expansion of new political parties such as the Five Star Movement in Italy, Podemos in Spain and the international Pirate Party seems to confirm this conclusion.

Digital technology and new social media are sometimes seen as promoting single-issue politics by making it easier to mobilize large numbers of protesters, nationally and internationally, over particular issues. One such example, on which this article will focus more closely, is the protest against the expansion of copyright and digital surveillance laws, which has given rise to a range of different activist groups and, for the most part, temporary campaigns that together constitute something that can be called a pirate movement $[3,6,7,10-12]$. This article will focus on the most explicitly politicized part of that movement, the Pirate Party: a political actor that began in Sweden in 2006 as a single-issue party focusing on filesharing and digital rights but quickly developed into something much wider.

This article draws on a larger study involving a series of semi-structured interviews with Pirate Party members in Sweden, the UK, Germany, the USA, and Australia, conducted between 2011 and 2013. The interviews in the USA were conducted between December 2011 and May 2012, with follow-up interviews in May 2013. The European interviews were conducted between 2012 and 2013, and the Australian interviews were conducted in 2013. Among the 31 people interviewed for the entire project, five were women. Most informants were between 20 and 40 years old. All participants play important roles in their local Pirate Party community, but these roles differ significantly due to the heterogeneity of the pirate parties. Although two of the interviewees were members of the European parliament at the time of the interviews, the vast majority were amateurs dedicating their spare time to party work. All the interviews were carried out in person, in most cases individually, with the exception of three interviews with groups of two to three participants. They were recorded, and all participants agreed to be quoted by name. The interviews were semi-structured in that they broadly followed an interview guide based around four thematic clusters: the participant's individual motivations, the organization of the party, the ideology of the party, and the national and international context of the party. The interviews also allowed for individual variations within those themes. The material was analyzed following a qualitative, inductive methodology.

The interviews give a number of different perspectives on the Pirate Party movement that I have explored in previous articles, focusing on the Pirate Party's relation to information technology [6], cultural enlightenment [12], democracy [7,11], the crisis of capitalism [13] and on the conflicts between parliamentary and extra-parliamentary modes of political organization [3]. Many of these issues and dilemmas connect to the Pirate Party's development towards a wider democracy movement. 
The purpose of this concluding article is to discuss that shift from being a single-issue to a multiple-issue party and analyze how the Pirate Party's initial preoccupation with filesharing technologies and open-source philosophy has promoted a wider political agenda. It focuses particularly on the pirate parties in the USA, Sweden and Germany but will eventually also consider recent developments in Iceland. Although the Icelandic Pirate Party was not part of the empirical study, it adds an important contrast to the other cases as it expanded swiftly in 2015 and 2016, while most other pirate parties were shrinking. This persistence, along with the party's capability to act on different political and (inter)national arenas and address a wide range of dilemmas, highlights the Pirate Party's continuous relevance as an object of study and possibly also as a political actor. Eventually the article will take the Pirate Party as an example to challenge the assumption that digital activism and social media-based movements tend to have a single-issue focus.

\section{Expanding the Pirate Agenda: From Information Politics to Democracy}

The first Pirate Party was formed in Sweden in 2006 as a reaction against harsher copyright laws and increased anti-terrorist surveillance. The party swiftly spread across Europe, North America, and Australia. Before the end of 2006, several other national pirate parties were formed, and an international coalition, Pirate Parties International, was initiated. In the EU elections of 2009, the Swedish Pirate Party won two seats in the European parliament, and in 2011, the German Pirate Party made major inroads in regional elections across the country $[6,10,11]$. However, in the subsequent years the expansion slowed. The Swedish Pirate Party lost its two seats in the European parliament in 2014 and received an all-time low number of votes in the national elections the same year. The German Pirate Party suffered surprisingly poor results in the federal election of 2013, and even though it won one seat in the European parliament in 2014, it had expected many more [14,15]. By the end of 2014, the Pirate Party movement seemed to be waning, but in late 2015 and early 2016, polls indicated that the Pirate Party had become the largest party in Iceland. Despite being founded as late as 2012, the Icelandic Pirate Party made a significant impact in the national election of 2013, where it received five percent of the votes, giving it three seats in the parliament. That the party won a staggering $35 \%$ of the support in several consecutive polls in 2015 and 2016 suggests that it might still be too early to discard the Pirate Party $[16,17]$.

Initially, the party's agenda focused on legalizing filesharing and protecting privacy online. The first wave of mobilization largely took place on online forums that attracted people interested in filesharing and digital rights $[3,6,7,10-12]$. Contrary to the common conception that the Pirate Party was merely a party of discontent, Erlingsson and Persson have shown that the early supporters were predominantly attracted by the party's consistent focus on digital rights issues [18]. The early Pirate Party also strongly emphasized that it would stick solely to those core issues. The emerging Pirate Party provides a good example of how the new (post)political landscape in general, and the rise of social media in particular, promotes single issues as the basis for political mobilization. The development of the party after its initial phase nevertheless challenges this assumption.

In the years following its success in the EU elections of 2009, the party's initial focus on copyright, privacy, and information politics gave way to a broader agenda. In a study of the official programs of the pirate parties in the Czech Republic, Finland, France, Germany, and Sweden, Johanna Jääsaari and Jockhum Hildén conclude that "the political agenda of European pirate parties is much wider today than before, incorporating a broad cultural-modernization program that goes beyond the confines of narrow technical policies" ([19], p. 884). Although they argue that the pirate parties maintained a focus on digital rights and privacy, they also claim that a wide range of different issues entered their agenda between 2011 and the EU elections in 2014 [19]. This is confirmed in a study by Bert Cammaerts, who argues that the German Pirate Party in particular has focused increasingly on the "crisis of representative democracy" ([20], p. 23).

The interviews imply that such a tendency to move beyond information politics and address the bigger problem of democracy has become a common denominator in most pirate parties (for further 
discussions see $[3,6,7,11-13])$. The opening lines of the UK Pirate Party manifesto encapsulate the sentiment of many of the interviewees when it defines the protection of democracy (rather than information politics) as the basis for the party's existence:

Democracy is in crisis in the United Kingdom. Whether it is online or on the doorstep, people are telling us that they feel alienated, ignored, that they have given up voting as it changes nothing ([21], p. 2).

The idea that democracy is at a crisis point is essentially present in all the national pirate parties [6,7]. This post-political assumption flows consistently from the party's focus on copyright legislation, which many of the interviewees see as largely corrupt given that the lawmaking process is heavily influenced by corporate interests and their lobbyists. Chris Walsh from the Massachusetts Pirate Party concludes that "there will be no fixing copyright until you fix the underlying problem with the influence of money on politics" [22]. Lawrence Lessig-well known for his critique of expansive copyright regimes-reaches the same conclusion in his 2011 book Republic Lost, focusing on the state of American democracy. In Republic Lost, Lessig describes how he was forced to shift his attention from copyright to wider democracy issues since all constructive reforms were blocked by the major parties' dependence on corporate funders. He goes on to argue that this is not an isolated phenomenon, but rather a symptom of a structural corruption entrenched in the entire political apparatus [6,23].

Although the focus on democracy may come naturally from the initial interest in information politics, the attempts to widen the agenda are also the result of strategic processes that have taken different shapes in different countries. The former head of the youth branch of the Swedish Pirate Party, Gustav Nipe, compares the reforms in the German Pirate Party to the conflict between fundamentalists and pragmatists in the German Green Party in the 1970s. According to Nipe, the German Pirate Party went through a similar conflict in 2010 and 2011 when the fundamentalists, here called the "Kernis", wanted the party to focus exclusively on its core values, while the pragmatists, the "Vollis", argued for a wider agenda. Just as within the Green Party, the Vollis side won [24-26]. In the German Pirate Party, the Vollis and Kernis opposition has been described as a partially geographic opposition between the northern districts, where the urge to widen the agenda was strong, and the southern districts, where many members preferred to stick to the core issues. In an interview in the German magazine TAZ, Sebastian Nerz from the Pirate Party in Baden-Württemberg related this to cultural and ideological differences, wherein the southern pirates tended to be somewhat more conservative [26].

The decision to widen the agenda appeared to pay off well, as the German Pirate Party, with its new platform, made a significant impact on many regional elections in 2011. As Nerz implied when he associated the Kernis with conservatism, the widening of the agenda tended to move the party somewhat towards the left/progressive side, as it included issues such as basic income, free public transport, and the legalization of light drugs. Unlike many Pirate Party members in other parts of Europe who refuse to take a position on the left-right axis, Cornelia Otto from the Berlin Pirate Party explicitly acknowledged that the Pirate Party was a left-wing party. She went on to describe how the German Pirate Party had even developed a comprehensive agenda on economic policies to counter the financial crisis that Europe suffered from at the time [27].

The Swedish Pirate Party went through a somewhat similar phase in 2011 and 2012 when the party initiated a process to widen its political agenda, partly inspired by the successes in Germany. In August 2011, a blog was launched where members could post and discuss suggestions on what positions the party should take on a wide range of political issues. In March 2012, a committee of active party members edited the propositions into a comprehensive party program, which was approved by the members with almost total support [28]. Something resembling a transition from Kernis to Vollis had occurred, but unlike in the German case it had taken place without any immediate turmoil. Before the process was initiated, Sammy Nordström from the party's national board expressed a concern that such a widening of the agenda could disrupt the party [29]. When the Swedish Pirate Party was formed, it also made a clear pledge not to address any areas other than the original core 
issues of respect for privacy online, freedom of information, and the critique of the expansion of intellectual property rights $[6,10,11]$.

Although the party backing down on this promise of a focused agenda could have caused concern, the interviewees I spoke to during and shortly after the period of agenda revision described the process as almost entirely uncontroversial. Both Nipe and Lindgren believed this was a consequence of the failure in the 2010 national election, which made it clear to the members that the agenda had to be changed to have a wider impact $[24,30]$.

Nevertheless, in the following years, conflicts surfaced in the Swedish Pirate Party. In December 2014, the party suffered a crisis of leadership when party leader Anna Troberg, deputy leader Marit Deldén, and party secretary Henrik Brändén left due to internal conflicts over the party's position on gender and LGBT rights [31]. This exposed a more fundamental conflict within the party, where the potential opposition between the Kernis and Vollis was acted out over the issue of gender and sexuality. In the blog post announcing her resignation, Troberg urged the party to continue to widen the agenda in spite of the silent opposition this had met within the party's board:

During my time as party leader, the Pirate Party has gone from a narrow focus party that puts technology at its core to a party that raises its gaze, thinks in broader perspectives and puts the human being at its core. It is a development that has been made possible by many brave pirates who have seen the potentials in the party's core principles and dared to apply them in a wider range of areas and made them relevant for all different kinds of people. [...] Let's give the party a chance to survive in the long run as something more than a mere social club for white, heterosexual men with an interest in technology [31] (my translation).

Although few members would object to embracing democracy, transparency, and participation as fundamental values in the pirate agenda, conflicts arose when these were applied to more specific and sometimes to more contested issues. The wider agenda covered a range of different areas, but it was hardly a coincidence that the opposition focused on the role of gender and sexuality, where some party members objected to making feminism and sexual politics a profile issue for the party and felt that the party leaders were giving up the party profile in favor of mainstream political correctness [31].

\section{Netpresence and the Meaning of Social Media}

Parallel to establishing a wider agenda, the Pirate Party also developed into an international movement, largely formed through already-existing social media networks, where members actively exchanged ideas and advice with party colleagues in other countries. However, many Pirate Party members also saw themselves as part of a wider international solidarity movement [3]. The expanding digital sphere not only promoted struggles for social change across the world, but also created new interfaces between those struggles. Pirate Party activists consequently established connections with a multitude of local and global social movements. While the relationship between European and American pirate parties and North African protesters might seem far-fetched to outsiders, many of the Pirate Party activists see themselves as part of an international heterogeneity of protest movements.

In his pamphlet The Netpolitical Manifest, the Swedish activist and sociologist Christopher Kullenberg discusses the emerg(ence of a new mode of existence that he calls "Netpresence" ("nätvaro": my translation). Netpresence is characterized by the ways of relating to and communicating with other people, locally and globally, that the Internet enables. This also gives rise to "Netpolitics"- the struggles regarding how to relate to and regulate the Internet:

The internet today is threatened by several political processes that aim to limit and block it. [...] Egyptian bloggers are arrested for criticizing regimes, countries like China and France force internet users to install governmental spy software in their computers, and in Sweden all traffic to and from abroad is copied and monitored by Försvarets Radioanstalt. While these state interventions mark contemporary regulation of the internet, many big companies, such as Apple, Google, and Microsoft, aim to limit communication on the 
internet and tie it to their commercial services [...] They thus stand in the way of the neutral movement of traffic that has been the prerequisite for the development of the computer networks. [...] When the netpresence is forced to defend itself, a netpolitics whose strength we have hitherto only seen at its first bleak stages, arises ([32], p. 22, my translation).

Netpolitics is a defense of the autonomy of a digital infrastructure, which can, if it remains free from control and restrictions imposed by commercial and authoritarian interests, form the basis for a globally interconnected heterogeneity of cloud protesting [4,5]. It is significant that this is articulated as an international struggle not only against Euro-American copyright expansionism, but also against human rights violations in countries such as China and Egypt. That Kullenberg particularly targets those regimes' violation of free digital communication highlights how human rights are seen as intertwined with increasingly globalized and digitized communicative technologies.

The relation to other social struggles is a reoccurring theme in the interviews with Pirate Party members. Zacquary Adams Green from the New York Pirate Party sees the open-source philosophy as the common denominator that connects the Pirate Party with the Arab Spring and a new generation of social movements:

I would venture to say that Richard Stallman, who founded the free software movement, is probably as responsible for the Arab Spring as any of the other major players because their organizational structure came almost directly from what the Open Source movement has been doing since the 1980s [33].

If Adams Green sees a parallel genealogy between the Open Source movement and the Arab Spring, then Travis McCrea, active in the American and Canadian pirate parties and in Pirate Parties International, goes even further, and claims that the pirate movement was essentially the origin of the Arab Spring:

I see the Occupy movement as a thing that came from the Pirate Party. I think that we created the Occupy movement. And maybe that's bold of me to say but, again, Tunisia was where everything started. And the Occupy movement came from the protests in Egypt [...] which came from the protest that started in Libya [meaning Tunisia] and Libya's [meaning Tunisia's] protest was started by a Pirate Party member, all the while being encouraged by Pirate Parties International [...] and when the Egyptians did their thing we were instrumental... [34].

McCrea speaks particularly about the Pirate Party member and digital activist Slim Amamou, who came to play an important role in the Tunisian revolution (which McCrea later mistakenly refers to as Libya). He also refers more generally to how members of an international digital rights movement supported the protesters by providing access to digital media channels. The Swedish activist group Telecomix, for instance, helped the rebels in Syria and Egypt to evade the authorities' attempts to shut down Internet communication [35]. This can be regarded as a direct intervention by a European pirate movement, since Telecomix was formed by Kullenberg and a few others in relation to The Pirate Bureau and The Pirate Bay [36]. Anonymous, in turn, collaborated with Slim Amamou by launching a well-organized campaign against Tunisian government websites [37].

Andrew Norton discards McCrea's statement as somewhat "grandiose", but he agrees that there is a connection between the pirate movement and the Arab Spring:

... the Arab Spring, the Occupy movement, and the pirate movement all stem from the same thing...they all come from the same source, which is an increasing oppression and lack of transparency; I think the old boys' networks are being more and more blatant [38].

Even though Norton is skeptical towards the Occupy movement, he still sees the Pirate Party, the Occupy movement, and the protesters in North Africa as different but parallel responses to 
obsolete power structures across the world, "from the political side, the activist side, and the armed rebellion" [38].

Birgitta Jonsdottir from the Icelandic Pirate Party also sees the party's impact as part of a wider global realization that the old political institutions have become corrupted and inadequate to represent contemporary political struggles: "It's all a part of the transformative times we're living in [...] people are realizing their democracies are not what they are supposed to be [...] Young people in particular find it unacceptable that they can only wield influence once every four years" [17].

Even if few of the interviewees go so far as to declare the Pirate Party the source of the Arab Spring, many of them see it as part of a multitude of democratic movements. This sense of international solidarity rests not only on the organizational and ideological levels, but also on a personal level where new information technology enables individual relationships across the world. As Jay Emerson points out: "The more we realize that we are not different, the more peaceful we can be in the future, when our generation is coming up" [39]. Emerson describes how he, during the revolution in Tunisia, closely followed the fate of Slim Amamou and contacted the embassy when he was incarcerated by the regime. Emerson concludes: "A friend, despite their location, is still a friend" [39]. Many of the interviewees have similar international contacts, which corresponds with the common notion that social movements today tend to be based more on personal relations than on collective ideologies and identities. The importance of personal relations is particularly dominant in transnational movements and the Twitter-based networks that formed within the Arab diaspora in relation to the Arab Spring [40]. As such, these are typical examples of the "transnational framing" that Stefania Milan sees at work among many groups of "radical techies": "This transnational framing inspires a sort of transnational imaginary-that is to say a common 'mental picture' of activism that works as a homogenizing force, fostering mutual recognition" ([5], p. 138).

That "transnational imaginary" of pirates and other "radical techies" is threatened by censorship imposed not only by what are essentially authoritarian governments, but also by copyright regimes. Apart from prohibiting the sharing of culture in general, copyright is also, according to Adams Green, a threat to the free dissemination of politically progressive ideas:

These ideas spread in unpredictable manners and show up in unpredictable ways, which is why we are advocating a lack of intellectual property because it's a barrier to ideas spreading and changing and mutating and morphing, and when you allow them to do that, wonderful things happen [33].

The free development of information technology is thus a prerequisite for social and political progress, which explains why the question of digital freedom is so central to the pirate ideology. In an affectionate outburst, Jay Emerson describes a free Internet as a matter of immense importance: "To let government regulate it [the Internet]—-more censorship basically—is allowing them to take away the future of humanity." This emphatic statement tells of the central position that information technology takes in the pirates' vision of a democratic society. Many of the interviewees express an almost utopian idea that society is at a crossroads where new technology can give rise to a more democratic and enlightened world characterized by global solidarity and the free sharing of knowledge and culture, but that the attempts to privatize and censor the Internet threaten to undo this brighter "future of humanity".

The trust in information technologies tends to rely on an underlying assumption that the unrestricted exchange of ideas creates harmony and consensus. Bert Cammaerts discusses this in relation to the decision-making model Liquid Democracy: a digital voting platform mainly used by the German Pirate Party where each member gets a vote on every decision but also has the right to pass that vote on to any other member it considers more competent on that particular issue. This is supposed to enhance direct democracy within the party but some argue that it may instead concentrate power into the hands of the most active and initiated members [20]. Cammaerts describes the belief that a perfect voting system creates consensus as a "Habermasian denial of the inherently 
conflictual nature of the political", expressed in the pirate parties' tendency to assume that an astute decision-making process can overcome differences of interest and reach a common position through collective reasoning ([20], p. 33).

The actual role of social media in the immediate street protests in North Africa has also been questioned. Thomas Poell and Kaouthar Darmoni, for instance, argue that although Twitter was of crucial importance for the Tunisian protesters' communication with the international press and Tunisian diasporas across the world, it only played a marginal role in the organization and coordination of the protests on the ground. This does not diminish the importance of social media, but as Poell and Darmoni ([40], p. 15) point out, there is a risk of reductionism if we let single technologies become "fetishized and personified" and make them represent a far more complex social context. In this case, one may also ask if supporters in Europe and America might give Western technologies disproportional credit for the developments in North Africa and the Middle East simply because it is through those technologies that these developments become most easily accessible to outsiders. It is also ironic that proponents of a political movement that opposes the appropriation of culture and knowledge can lay claim to an entire revolution. Associating the Arab Spring with open-source philosophy runs the risk of reducing a diversity of social and political struggles that have been taking place in North Africa and the Middle East for decades to mere expressions of a philosophy developed by white men in Europe and North America in the 1980s and 1990s. Even though digital technology indeed provides new means for global communication and solidarity, which the connections between European and American pirates and North African protesters highlight, this cannot simply erase centuries of colonialism and the unequal distribution of resources.

Just as the widened agenda turned out to be potentially problematic for many members, connecting to other social movements can also be controversial within some pirate parties. Few within the pirate parties in Europe or the USA would question their solidarity with people protesting against oppressive regimes in Tunisia and other distant places, but the relation to activist groups closer to home can be more sensitive. As I have shown elsewhere, the connection with movements such as Anonymous and Occupy Wall Street has created much disruption within the American Pirate Party, where this is seen as a radicalization that threatens the Pirate Party's credibility as a legitimate actor in a representative democracy [3]. The results of this study are partly contradictory: on the one hand, both the holistic agenda and the wider global alliances might deter some members who think that the party should stick to its core values. On the other hand, the extended agenda and sphere of alliances seem to come naturally from a globally shared Pirate Party mentality that has grown out of the party's original focus on information technology. Although the idealization of social media as a harmonizing force can be questioned, its fundamental political significance is uncontestable. The final part of this article will discuss how this significance forms a precondition for the Pirate Party's development into a wider democracy movement.

\section{The Wider Implications of Information Politics: Lessons from Iceland}

The belief that the future of humanity relies on the freedom of the Internet reflects an understanding of the Internet as a truly social media: that is, as a media that can connect and empower people across the world regardless of geographical, political or cultural barriers, and without the intermediation and regulation of corporations or governments. This is essentially an extension of the peer-to-peer philosophy endorsed by early Pirate Party supporters, but applied to political communication and not just entertainment, which gives it much wider political implications and inherently shifts the focus from information politics to fundamental democracy issues. Most new parties rely heavily on social media as a tool for political campaigning. What characterizes the Pirate Party, however, is that social media is not only a political tool, but the movement's main political cause. Social media in this case is not synonymous with certain digital forums, such as Facebook or Twitter, or even with new and more technologically elaborate ways to conduct mass communication in general. Social media means a realization of the Internet's inherent potential to serve as a global, 
decentered and unrestricted peer-to-peer network for political communication. This is a holistic and organic view on social media that is seen not as a delineable media phenomenon that can be utilized for certain purposes but as a fundamental and ever-present dimension of contemporary society. This holistic perspective is part of a philosophy and value system that the Pirate Party shares with a wide range of open-source and digital rights movements that can be described with Milan's term "radical techies" [5].

Both the widening of the Pirate Party agenda and its relation to movements such as Occupy Wall Street and the Arab Spring protesters stem from a politicization of the infrastructure for communication. In The Internet Galaxy, Manuel Castells discusses the emergence of a "culture of Internet", which is in fact divided into several different cultures that Castells identifies as a "techno-meritocratic culture", a "hacker culture", a culture of "virtual communitarians", and an "entrepreneurial culture" [41]. These cultures embrace different values and goals, but they all share a particular respect for the freedom of the Internet and the open access to culture and information that it provides.

The strong netpresence of many of the Pirate Party's followers also promotes a certain political sensibility and subjectivity as the pirates see themselves as actors in a global political network that needs to be maintained and defended. This resembles what the anthropologist Christopher Kelty calls a "recursive public". Kelty uses the term to describe the hacker community as an extraordinarily self-reflexive public sphere that is fundamentally concerned with protecting, developing, and discussing its own norms and protocols for communication. This can be seen, for instance, in the central position that open source and creative commons take in free and open-source communities, not only as technological and legal methods but also as a set of norms that regulate the circulation of information ([42], p. 298).

Kelty's definition of the recursive public also corresponds with how Stefania Milan describes the role of the network for the radical techies:

For radical techies the network is at the same time a metaphor for, and the concrete structure of, their organization. Techies represent a paradigmatic model of network. They create networks in cyberspace that allow other people and groups to create and maintain their own social networks ([5], p. 152).

The free network becomes not only a model for their own organizational structure, but also a communicative ideology stipulating that everyone across the world should enjoy that freedom of communication. The radical techies' willingness to create networks that can help other social movements is particularly evident in the relationship between Western hacktivists and protesters in North Africa and the Middle East. The way that Pirate Party activists see themselves as engaged in the same struggle as the protestors in Tunisia or Egypt bears witness to how the concept of digital rights can form the basis for a wider struggle for global solidarity and human rights, as new technology enables a more far-reaching globalization of different protest movements.

The impact of the Icelandic Pirate Party is an example of the far-reaching implications that the party's commitment to social media and information politics can have. The rapid growth of the Icelandic Pirate Party in late 2015 and 2016 has been explained as a reaction against the corruption of both politics and corporate life in Iceland. This crisis of trust dates back to the 2008 bank crisis, when the Icelandic banks bankrupted the country through the misuse of short-term credits and high-risk investments [43]. The political establishment's reluctance to interfere and the lack of critical voices in mainstream media (indirectly largely owned by the banks) created what Birgitta Jonsdottir, one of the Pirate Party's members of the Icelandic parliament, has described as not only a financial collapse but a collapse of the political institutions that the Icelandic people had put their trust in. Jonsdottir's party colleague Ásta Helgadóttir argues that the Pirate Party comes across as a new and less corrupt alternative for the voters, given that it was not formed until 2012 and thus was never compromised by the bank crisis [44].

The pirate movement in Iceland has, however, had a much more active role in the crisis than Helgadóttir acknowledges. Although the Icelandic Pirate Party was formed in 2012, it traces its 
origins back to a movement of radical techies that helped uncover the dealings behind the bank crisis. At an early stage Wikileaks had a strong base in Iceland, and in August 2009 Wikileaks released leaked documents revealing that Kaupthing had issued large and insecure loans to companies owned by some of the bank's largest shareholders. When a court order prohibited Icelandic news media from reporting on Kaupthing' s corrupt affairs, state TV referred the viewers to Wikileaks, making Wikileaks the main source of information for the Icelandic people [43]. At that stage, Birgitta Jonsdottir acted as Wikileaks' spokesperson in Iceland, which made her one of the few who publicly spoke up against the corruption [45,46]. Consequently, Jonsdottir also lobbied intensely for the so-called Icelandic Modern Media Initiative (IMMI): a new set of media laws enhancing freedom of information and offering better protection for journalists and whistleblowers that was passed by the Icelandic parliament in 2010 [47]. This reform in information politics thus becomes a part of the democratic reconstitution of the Icelandic democracy after the crisis of 2008.

This is another example of how the pirate movement's ethos of free information makes it active in political struggles that go well beyond a narrow focus on information politics. What sets the Icelandic Pirate Party apart from many other European counterparts is that its work with democracy issues did not stop with ideological declarations and global networking, but actually had a direct impact on national politics. This showed, in a very concrete way, that information politics is not a single issue but can have direct and fundamental implications on how a society is run. Furthermore, the Icelandic Pirate Party's close relation to Wikileaks also indicates that a strong connection to an international activist context may also strengthen the political agency and credibility on a national level.

This study undermines the polarization between single-issue movements and democracy movements. The Pirate Party example shows that although a movement might appear to have a strong single-issue focus, even in the minds of its own members, few political issues can be singled out and isolated from wider political struggles. The party's shift from single-issue politics to a wider agenda is thus merely apparent. The holistic agenda was there from the start-inherent in the peer-to-peer philosophy - it just had to be fleshed out as the movement matured. Instead of seeing the early Pirate Party as a single-issue party, it might be fruitful to speak of information politics as a focal point to address larger political issues regarding fundamental political rights and responsibilities in contemporary society.

Acknowledgments: This article is based on a research project entitled "The Ideology of Piracy", funded by The Swedish Foundation for Humanities and Social Sciences (Riksbankens Jubileumsfond).

Conflicts of Interest: The author declares no conflict of interest.

\section{References}

1. Beck, Ulrich. "Subpolitics: Ecology and the disintegration of institutional power." Organization E Environment 10 (1997): 52-65. [CrossRef]

2. Beck, Ulrich. The Risk Society: Towards a New Modernity. London: Sage, 1992.

3. Fredriksson Almqvist, Martin. "Pirate politics between protest movement and the parliament." Ephemera 16 (2016): 99-116.

4. Milan, Stefania. "Wikileaks, anonymous and the exercise of individuality: Protesting in the cloud." In Beyond Wikileaks: Implications for the Future of Communications, Journalism and Society. Edited by Bernadette Brevini, Arne Hintz and Patrick McCurdy. Basingstoke: Palgrave Macmilliam, 2013, pp. 191-209.

5. Milan, Stefania. Social Movements and Their Technologies: Wiring Social Change. Basingstoke: Palgrave Macmilliam, 2013.

6. Fredriksson, Martin. "The pirate party and the politics of communication." International Journal of Communication 9 (2015): 909-24.

7. Fredriksson, Martin, and James Arvanitakis. "Piracy, property and the crisis of democracy." Journal of Edemocracy and Open Government 7 (2015): 135-50.

8. Chadwick, Andrew. "Digital network repertoires and organizational hybridity." Political Communication 24 (2007): 283-301. [CrossRef] 
9. Chadwick, Andrew, and Jennifer Stromer-Galley. "Digital media, power, and democracy in parties and election campaigns: Party decline or party renewal? " International Journal of Press/Politics 21 (2016): 1-11. [CrossRef]

10. Burkart, Patrick. Pirate Politics. Cambridge: MIT Press, 2013.

11. Fredriksson, Martin. "An open source project for politics: Visions of democracy and citizenship in american pirate parties." In The Citizen in the 21st Century. Edited by James Arvanitakis and Ingrid Matthews. Witney: Inter Disciplinary Press, 2013, pp. 201-13.

12. Fredriksson, Martin. "Pirates, librarians and open source capitalists: New alliances in the copyright wars." In Copyrighting Creativity: Creative Values, Cultural Heritage Institutions and Systems of Intellectual Propert. Edited by Helle Porsdam. Farnham: Ashgate, 2015.

13. Arvanitakis, James, and Martin Fredriksson. "Commons, piracy and the crisis of property." Triple C 14 (2016): 132-44.

14. Valmyndigheten. "Val Till Riskdagen: Röster." Available online: http://www.val.se/val/val2014/ slutresultat/R/rike/index.html (accessed on 10 June 2016).

15. Pham, Khue. “Es Waschön Mit Euch.” Die Zeit, 25 September 2014. Available online: http:/ /www.zeit.de/ 2014/40/piraten-lauer-domscheit-berg (accessed on 10 March 2016).

16. Valdimarsson, Omar R. “Arr! Forget Icesave, Iceand's Next Scare is the Pirate Party! " Financial Revieew, 19 January 2016.

17. Rogers, John. "Hacking Politics: An in-Depth Look at Iceland's Pirate Party." The Reykjaviik Grapevine, 19 November 2015.

18. Erlingsson, Gissur O., and Mikael Persson. "The swedish pirate party and the 2009 european parliament election: Protest or issue voting? " Politics 31 (2011): 121-28. [CrossRef]

19. Jääsaari, Johanna, and Jockum Hildén. "From file sharing to free culture: The evolving agenda of european pirate parties." International Journal of Communication 9 (2015): 879-89.

20. Cammaerts, Bert. "Pirates on the liquid shores of liberal democracy: Movement frames of european pirate parties." Javnost-The Public 22 (2015): 19-26. [CrossRef]

21. Pirate Party UK. “Manifesto." 2012. Available online: https://www.pirateparty.org.uk/media/uploads / Manifesto2012.pdf (accessed on 3 August 2016).

22. Walsh (Pirate Party, Boston, MA, USA). Interview, 8 December 2011.

23. Lessig, Lawrence. Republic, Lost: How Money Corrupts Congress-And a Plan to Stop it. New York: Twelve Books, 2011.

24. Nipe (Pirte Party, Uppsala, Sweden). Interview, 1 November 2012.

25. Becker, Sven, Markus Feldenkirchen, Marcel Rosenbach, and Merlind Thiele. "Political Neophytes: Do the Berlin Pirates Have a Nationwide Future? " Der Spiegel, 26 September 2011.

26. Laaf, Maaf. “Kernis gegen vollis.” TAZ.de, 2010. Available online: http://www.taz.de/!5131898/ (accessed on 3 August 2016).

27. Otto (Piirate Party, Berlin, Germany). Interview, 3 June 2013.

28. Piratpartiet. “Nu breddar vi Piratpartiet." Available online: http://breddning.piratpartiet.se/process / (accessed on 10 June 2016).

29. Nordström (Pirate Party, Stockholm, Sweden). Interview, 21 September 2011.

30. Bjernemalm (Pirate Party, Brussels, Belgium). Interview, 2 October 2012.

31. Troberg, Anna. “Ajöss och Tack för Fisken.” Anna Troberg, 1 December 2014.

32. Kullenberg, Christopher. Det Nätpolitiska Manifestet. Stockholm: Ink Bokförlag, 2010.

33. Adams Green \& Brunner (Pirate Party, New York, NY, USA). Interview, 2 April 2012.

34. McCrea (Pirate Party, Vancouver, BC, Canada). Interview, 2 March 2012.

35. Madlena, Chavala. "Tech Support for the Arab Spring." The Guardian, 7 July 2011.

36. Wikipedia. "Telecomix." Available online: http://en.wikipedia.org/wiki/Telecomix\#Origins (accessed on 4 September 2013).

37. Coleman, Gabriella. Hacker, Hoaxer, Whistleblower, Spy: The Many Faces of Anonymous. London and Brooklyn: Verso, 2014.

38. Norton (Pirate Party, Marietta, GA, USA). Interview, 12 March 2012.

39. Emerson (Pirate Party, New York, NY, USA). Interview, 21 April 2012. 
40. Poell, Thomas, and Kaouthar Darmoni. "Twitter as a multilingual space: The articulation of the tunisian revolution through \#sidibouzid." NECSUS: European Journal of Media Studies 1 (2012): 14-34.

41. Castells, Manuel. The Internet Galaxy: Reflections on the Internet, Business, and Society. Oxford: Oxford University Press, 2001.

42. Kelty, Christopher. Two Bits: The Cultural Significance of Free Software. Durham: Duke University Press, 2008.

43. Sigurjonsson, Thorstur O. "The icelandic bank collapse: Challenges to governance and risk management." Corporate Governance: The International Journal of Business in Society 10 (2010): 33-45.

44. Möller, Jens. "Piratpartiet Störst på Island." Sveriges Radio, 2016. Available online: http:/ /sverigesradio.se/ sida/artikel.aspx?programid=83\&artikel=6379750 (accessed on 4 August 2016).

45. Withnal, Adam. "Iceland's Pirate Party Takes Big Lead in Polls ahead of Election Next Year." The Independent, 26 January 2016.

46. Knight, Sam. "Icelandic Activist Birgitta Jónsdóttir Explains How Wikileaks Changed Her Country Forever." Take Part, 18 October 2013.

47. Postill, John. Freedom Technologists and the Future of Global Justice. Amsterdam: Transnational Institute, 2016.

(C) 2016 by the author; licensee MDPI, Basel, Switzerland. This article is an open access article distributed under the terms and conditions of the Creative Commons Attribution (CC-BY) license (http://creativecommons.org/licenses/by/4.0/). 